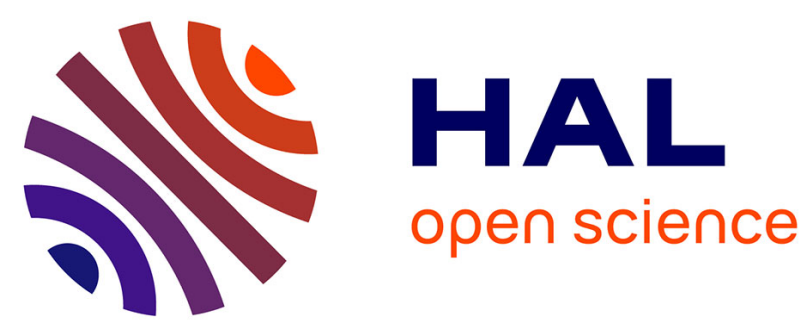

\title{
Expression and characterization of honeybee, Apis mellifera, larva chymotrypsin-like protease
}

Takuma Matsuoka, Akihiko Takasaki, Tomoyuki Mishima, Takuji Kawashima, Yoshihiro Kanamaru, Tadasi Nakamura, Tomio Yabe

\section{- To cite this version:}

Takuma Matsuoka, Akihiko Takasaki, Tomoyuki Mishima, Takuji Kawashima, Yoshihiro Kanamaru, et al.. Expression and characterization of honeybee, Apis mellifera, larva chymotrypsin-like protease. Apidologie, 2015, 46 (2), pp.167-176. 10.1007/s13592-014-0313-2 . hal-01284435

\section{HAL Id: hal-01284435 \\ https://hal.science/hal-01284435}

Submitted on 7 Mar 2016

HAL is a multi-disciplinary open access archive for the deposit and dissemination of scientific research documents, whether they are published or not. The documents may come from teaching and research institutions in France or abroad, or from public or private research centers.
L'archive ouverte pluridisciplinaire HAL, est destinée au dépôt et à la diffusion de documents scientifiques de niveau recherche, publiés ou non, émanant des établissements d'enseignement et de recherche français ou étrangers, des laboratoires publics ou privés. 


\title{
Expression and characterization of honeybee, Apis mellifera, larva chymotrypsin-like protease
}

\author{
Takuma MATSUOKA $^{1}$, Akihiko TAKASAKI ${ }^{2}$, Tomoyuki Mishima ${ }^{2}$, Takuji KaWASHIMA ${ }^{1}$, \\ Yoshihiro KANAMARU ${ }^{3}$, Tadasi NAKAMURA ${ }^{1}$, Tomio YABE $^{3}$ \\ ${ }^{1}$ Akitayahonten Co., Ltd., 1-1 Kanoufuji-machi, Gifu, Gifu 500-8471, Japan \\ ${ }^{2}$ Department of Medical Technology, Gifu University of Medical Science, 795-1 Nagamine, Ichihiraga, Seki, Gifu 501-3892, \\ Japan \\ ${ }^{3}$ Department of Applied Life Science, Gifu University, 1-1 Yanagido, Gifu, Gifu 501-1193, Japan
}

Received 30 April 2014 - Revised 22 July 2014 - Accepted 15 August 2014

\begin{abstract}
Previously, we found three enzyme fractions containing activities for the hydrolysis of royal jelly proteins from honeybee queen larvae. In this study, we identified a honeybee chymotrypsin-like protease (HCLPase) by LC-MS/MS and expressed it as a recombinant protein in Escherichia coli. The protease had an estimated molecular weight of around $26 \mathrm{kDa}$ and showed high specificity for succinyl-Ala-Ala-Pro-Phe $p$-nitroanilide as a proteolytic substrate. Furthermore, the protease had an optimal $\mathrm{pH}$ of 9 , and the activity was markedly inhibited by phenylmethylsulfonyl fluoride but not tosyl phenylalanyl chloromethyl ketone, both of which are irreversible inhibitors of chymotrypsin-like serine proteases. These results suggested that this recombinant protease, HCLPase, was a chymotrypsin-like serine protease with different characteristics from mammalian chymotrypsin.
\end{abstract}

\section{Apis mellifera / queen larva / chymotrypsin-like protease}

\section{INTRODUCTION}

The honeybee, Apis mellifera, is a social insect with several castes. The queen or workers are determined in the caste by food in the larval period. Royal jelly (RJ), a nutrient for the queen and larvae, is secreted from the hypopharyngeal and mandibular glands of worker bees and plays a critical role in the differentiation of the queen. RJ is a protein-rich food (about $40 \%$ of dry mass) and a $57-\mathrm{kDa}$ protein in $\mathrm{RJ}$, royalactin, was recently reported to be crucial for queen differentiation (Kamakura 2011). On the other hand, several functional activities of RJ for human health have also been reported. RJ is commonly used as a health food in many countries. Furthermore, peptides from

Corresponding author: T. Yabe, yabet@gifu-u.ac.jp Handling Editor: Klaus Hartfelder
RJ proteins are produced by commercial proteases and show various properties, including antioxidant (Guo et al. 2008, 2009; Nagai et al. 2006), antihypertensive (Tokunaga et al. 2004; Matsui et al. 2002), antiosteoporotic (Hidaka et al. 2006), and cholesterol-lowering (Nakasa et al. 2003), as well as prevention of sarcopenia (Niu et al. 2013). However, it is not clear how the queen bee and larvae digest $\mathrm{RJ}$ in nature. We hypothesized that honeybee queen larvae may have efficient proteases for digestion of $\mathrm{RJ}$ to produce functional peptides.

Several digestive proteases, such as trypsin, chymotrypsin, cysteine proteases, aminopeptidases, and carboxypeptidases, have been found in insects (Terra and Ferreira 1994). Several reports have suggested that tryptic or chymotryptic activities play an important role in the digestion of food in the honeybee. Burgess et al. (1996) reported that Kunitz soybean trypsin 
inhibitor (SBTI) ingestion increased mortality of worker bees and decreased trypsin, chymotrypsin, and elastase activities in the bee midgut. Correspondingly, honeybee larvae given $1.0 \%$ SBTI in food showed high mortality rates and low body weight although they developed to adults (Brødsgaard et al. 2003). In addition, Giebel et al. (1971) found four endopeptidases from the midgut of adult worker bees: one of the proteases was similar to bovine trypsin, and the others resembled bovine chymotrypsin. Among them, only one of these proteases was found in adult queen and worker larvae. The protease had chymotrypsin-like characteristics and was inhibited by tosyl-L -phenylalanine chloromethyl ketone (TPCK), a chymotrypsin inhibitor, but could not digest substrates of trypsin and chymotrypsin. The trypsin-like protease obtained from adult worker bees was not found in the queen bee or larvae. Dahlmann et al. (1978) investigated the changes in chymotryptic, tryptic, and aminopeptidyl protease activities occurring during the development of honeybee workers, i.e., in larvae before and after sealing, pupae, and adults. They showed changes in three protease activities in each developmental stage within the same caste. They also showed that chymotryptic activity in the larval stages decreased after sealing when they no longer required feeding.

The above reports suggest that it is possible that the chymotryptic enzyme plays an important role in the digestion of food by bee larvae. There are genes for 44 serine-type proteases and 12 serinetype protease homologs in the honeybee genome (Honeybee Genome Sequencing Consortium 2006; Zou et al. 2006). However, little information is available regarding the expression and function of proteases encoded by these honeybee serine protease genes.

Previously, we found three protease fractions that were capable of digesting RJ protein from 2- to 3-day-old honeybee queen larvae, including carboxypeptidase-A-like activity and chymotrypsin-like activity (Matsuoka et al. 2012). The present study was performed to identify the proteases from honeybee queen larvae and characterize the recombinant chymotrypsin-like protease expressed in Escherichia coli.

\section{MATERIALS AND METHODS}

\subsection{Separation and identification of proteases from honeybee queen larvae}

\subsubsection{Sample preparation}

Three-day-old honeybee queen larvae were obtained from Akitaya Honten Co., Ltd. (Gifu, Japan). Honeybee queen larvae were homogenized and filtrated using nylon mesh. The homogenate was diluted in an equal volume of $50 \mathrm{mM}$ phosphate buffer $(\mathrm{pH} 7.0)$ and then centrifuged at $10,000 \times \mathrm{g}, 4{ }^{\circ} \mathrm{C}$ for $20 \mathrm{~min}$. The clear yellowish middle layer was collected and filtrated first through a glass fiber filter (Advantec, Tokyo, Japan) and then a $0.20-\mu \mathrm{m}$ cellulose acetate filter (Advantec) to obtain the crude enzyme solution.

\subsubsection{Column chromatography}

The proteases were purified by cation exchange column chromatography and gel filtration column chromatography. The $\mathrm{pH}$ value of the cation exchange column chromatography was preliminarily examined for collecting enzymes showing higher specific activities. Aliquots of $5 \mathrm{~mL}$ of crude enzyme solution were loaded onto a 1-mL HiTrap SP HP column (GE Healthcare, Little Chalfont, UK) equilibrated with $20 \mathrm{mM}$ phosphate buffer ( $\mathrm{pH}$ 7.6). The column was washed with five column volumes of $20 \mathrm{mM}$ phosphate buffer $(\mathrm{pH}$ 7.6), and then the proteins were eluted with $20 \mathrm{mM}$ phosphate buffer ( $\mathrm{pH}$ 7.6) containing $0.5 \mathrm{M}$ $\mathrm{NaCl}$. Gel filtration chromatography was performed by the ÄKTAprime system (GE Healthcare). The eluent from the cation exchange column was loaded onto a HiLoad 16/600 Superdex 75 pg column $(1.6 \times 60 \mathrm{~cm}$; GE Healthcare) equilibrated with $50 \mathrm{mM}$ phosphate buffer containing $0.15 \mathrm{M} \mathrm{NaCl}$ ( $\mathrm{pH}$ 7.0). Proteins were eluted using the same buffer at a flow rate of $0.7 \mathrm{~mL} / \mathrm{min}$ with a fraction volume of $2 \mathrm{~mL}$ and detected by absorbance at $280 \mathrm{~nm}$.

\subsubsection{Chymotryptic and carboxypeptidase- like enzyme assay}

Chymotryptic protease activities were determined by hydrolysis of $N$-succinyl-L-alanyl-L -alanyl-L -prolyl-L phenylalanine $p$-nitroanilide (SAAPF $p$ NA; Sigma Aldrich, St. Louis, MO) as a substrate. The reaction 
mixture contained $386 \mu \mathrm{L}$ of $50 \mathrm{mM}$ Tris- $\mathrm{HCl}$ buffer $(\mathrm{pH} 9.0), 2 \mu \mathrm{L}$ of $50 \mathrm{mM}$ SAAPF $p$ NA in dimethylformamide, and $10 \mu \mathrm{L}$ of sample and was incubated at $37^{\circ} \mathrm{C}$ for $10 \mathrm{~min}$. The reaction was stopped by adding $20 \mu \mathrm{L}$ of glacial acetic acid. The absorbance of liberated $p$-nitroaniline was determined at $405 \mathrm{~nm}$. One unit of activity corresponded to the amount of enzyme that released $1 \mu \mathrm{mol}$ of $p$-nitroaniline per min under standard assay conditions.

The carboxypeptidase activities were determined using $N$-carbobenzoxy-glycyl-L -phenylalanine (ZGly-Phe; Sigma Aldrich) as a substrate. The reaction mixture contained $190 \mu \mathrm{L}$ of $1 \mathrm{mM}$ Z-Gly-Phe in Tris$\mathrm{HCl}$ buffer containing $0.1 \mathrm{M} \mathrm{NaCl}(\mathrm{pH} 9.0)$ and $10 \mu \mathrm{L}$ of the sample and was incubated at $37^{\circ} \mathrm{C}$ for $30 \mathrm{~min}$. The reaction was stopped by adding $600 \mu \mathrm{L}$ of $0.4 \mathrm{M}$ acetate buffer ( $\mathrm{pH}$ 5.0). The absorbance of liberated phenylalanine was determined by a ninhydrin assay (Moore 1968). One hundred microliters of sample was collected in other tubes, and $100 \mu \mathrm{L}$ of ninhydrin reagent ( $2 \%$ solution, Sigma Aldrich) was added. The sample was incubated at $100{ }^{\circ} \mathrm{C}$ for $15 \mathrm{~min}$. After incubation, $1 \mathrm{~mL}$ of ice-cold ethanol was added to the sample. The absorbance of liberated phenylalanine was determined at $570 \mathrm{~nm}$. One unit of activity corresponded to the amount of enzyme that released $1 \mu \mathrm{mol}$ of phenylalanine per min under standard assay conditions.

\subsubsection{Sodium dodecyl sulfate-polyacrylamide gel electrophoresis}

Proteins of the fractions including carboxypeptidase activity (fraction I) and chymotryptic activity (fraction II) collected by column chromatography were separated by sodium dodecyl sulfate-polyacrylamide gel electrophoresis (SDS-PAGE).

\subsubsection{Mass spectrometry and database search}

After SDS-PAGE, the excised protein spots were subjected to in-gel digestion with trypsin (Shevchenko et al. 1996). The samples were separated using a nanoflow multidimensional HPLC system (Paradigm MS4; Michrom BioResources, Auburn, CA) and analyzed by electrospray ionization ion trap mass spectrometry (ESI-ion trap MS) (LCQDECAXP; Thermo Fisher Scientific, Waltham, MA) under optimum conditions (capillary temperature, $200{ }^{\circ} \mathrm{C}$; capillary voltage, $3.0 \mathrm{~V}$; and spray voltage, $1.90 \mathrm{kV}$ ). Peptide sequences were searched against the protein database (MSDB) using Mascot software (Matrix Science Ltd., London, UK).

\subsubsection{N-terminal amino acid sequence}

After SDS-PAGE, fraction II proteins were transferred onto polyvinylidene difluoride (PVDF) membranes by electroblotting, and each band was separated. The N-terminal amino acid sequence of chymotrypsinlike protein was analyzed using a peptide sequencer (Model 491; Applied Biosystems, Foster City, CA) from blotted PVDF membrane pieces.

\subsection{Expression of the enzyme by recombinant $E$. coli}

\subsubsection{Target DNA amplification and recombinant vector construction}

Total RNA of honeybee queen larvae was prepared from whole larvae with a FastPure RNA kit (TaKaRa, Shiga, Japan). Total RNA was stored at $-80{ }^{\circ} \mathrm{C}$ before use. cDNA was prepared from total RNA by oligo(dT) primer (Toyobo, Osaka, Japan) and reverse transcriptase (ReverTraAce; Toyobo). Aliquots of $1 \mu \mathrm{g}$ of total RNA, $0.5 \mu \mathrm{L}$ of oligo(dT) primer, $4 \mu \mathrm{L}$ of $4 \times$ buffer, $8 \mu \mathrm{L}$ of $2.5 \mathrm{mM}$ dNTP mixture, $1 \mu \mathrm{L}$ of RNase inhibitor, and $1 \mu \mathrm{L}$ of ReverTraAce were mixed and incubated at $42{ }^{\circ} \mathrm{C}$ for $30 \mathrm{~min}$. The enzyme was deactivated by heating at $99{ }^{\circ} \mathrm{C}$ for $1 \mathrm{~h}$. Honeybee chymotrypsinlike protease DNA was amplified by PCR with the sense primer 5'-AAA GTC GAC ATT GTT GGC GGC AGT GAT G-3' containing a Sal I cleavage site and antisense primer 5'-AAAAA GAA TTC TAA GAA ATG TAG AAA CCG TCT GCT G-3' containing an Eco RI cleavage site. The PCR conditions were as follows: 1 cycle of $98{ }^{\circ} \mathrm{C}$ for $30 \mathrm{~s}$; 30 cycles of $98{ }^{\circ} \mathrm{C}$ for $10 \mathrm{~s}, 58{ }^{\circ} \mathrm{C}$ for $15 \mathrm{~s}$, and $72{ }^{\circ} \mathrm{C}$ for $20 \mathrm{~s}$; and 1 cycle of $72{ }^{\circ} \mathrm{C}$ for $5 \mathrm{~min}$.

To construct the recombinant $E$. coli, PCR products and Gateway ${ }^{\circledR}$ pENTR ${ }^{\mathrm{TM}} 1 \mathrm{~A}$ vector (Life Technologies, Carlsbad, CA) were digested with $\mathrm{Sal}$ I and Eco RI and ligated using T4 DNA ligase (New England Biolabs, Ipswich, MA). The ligated entry clone was transformed into competent $E$. coli $\mathrm{DH} 5 \alpha$ cells and selected on LuriaBertani (LB) medium plates containing $50 \mu \mathrm{g} / \mathrm{mL}$ kanamycin. The chymotrypsin-like protein-coding region of 
the entry clone was transferred into the pDEST15 vector by LR clonase (Invitrogen) in accordance with the manufacturer's instructions. Recombinant pDEST15 vector was transformed into competent $E$. coli $\mathrm{DH} 5 \alpha$ cells and selected on LB medium plates containing $100 \mu \mathrm{g} / \mathrm{mL}$ ampicillin. Positive clones were selected by PCR and sequenced (ABI Genetic Analyzer PRISM3100; Applied Biosystems).

Recombinant protein was expressed after inserting the recombinant vector into $E$. coli BL21 (DE3). Recombinant $E$. coli was cultured in LB medium containing $100 \mu \mathrm{g} / \mathrm{mL}$ ampicillin at $20{ }^{\circ} \mathrm{C}$ with $200 \mu \mathrm{M}$ isopropyl $\beta$-D-1-thiogalactopyranoside (IPTG). E. coli was collected by centrifugation at $5,000 \times g, 4{ }^{\circ} \mathrm{C}$ for $10 \mathrm{~min}$.

\subsubsection{Purification of recombinant protein}

Expressed protein was refolded using a Rapid GST Inclusion Body Solubilization and Renaturation Kit (Cell Biolabs, San Diego, CA). E. coli was resuspended in STE buffer accompanying the kit with $0.2 \mathrm{mg} / \mathrm{mL}$ lysozyme and $1 \mathrm{mM}$ dithiothreitol and lysed by sonication on ice. Each E. coli lysate was subjected to SDSPAGE, and recombinant protein expression was confirmed by comparison with the lysate without IPTG. In addition, to confirm the composition of the inclusion body, E. coli lysates were separated into soluble and insoluble protein fractions by centrifugation at $12,000 \times g, 4{ }^{\circ} \mathrm{C}$ for $15 \mathrm{~min}$, and protein composition was checked by SDS-PAGE. The inclusion body was solubilized and refolded using the kit according to the manufacturer's product manual.

Refolded recombinant GST-protein sample was filtrated through a $0.2-\mu \mathrm{m}$ membrane filter (Millipore, Billerica, MA). Aliquots of $500 \mu \mathrm{L}$ of glutathione sepharose 4B beads (50\% slurry; GE Healthcare) were added to $10 \mathrm{~mL}$ of the sample solution and incubated at room temperature with rotation. Beads were collected by centrifugation at $500 \times g$, room temperature for $5 \mathrm{~min}$. Three milliliters of phosphate-buffered saline (PBS) was added to the beads and centrifuged at $500 \times g$, room temperature for $5 \mathrm{~min}$, and the supernatant was discarded. This washing step was repeated a total of three times. Recombinant protein was cleaved out from the GST-tag by $200 \mu \mathrm{L}$ of $25 \mathrm{U} / \mathrm{mL}$ thrombin (GE Healthcare) in PBS at room temperature for $16 \mathrm{~h}$. Recombinant protein was collected by centrifugation at $500 \times g$, room temperature for $5 \mathrm{~min} ; 200 \mu \mathrm{L}$ of PBS was added to the beads followed again by centrifugation, and two supernatants were mixed. The protein concentration in the recombinant protein sample was measured by the Bradford method using the Bio-Rad Protein Assay (Bio-Rad Laboratories, Hercules, CA) and BSA as a standard.

\subsection{Characterization of the enzyme}

\subsubsection{Enzyme assay and substrate specificity}

The activities of the recombinant protein toward several serine protease substrates-SAAPF $p \mathrm{Na}$, succinyl-alanyl-alanyl-prolyl-leucine $p$-nitroanilide (SAAPL $p \mathrm{Na}$ ), succinyl-alanyl-alanyl-alanine $p$ nitroanilide (SAAA $p \mathrm{Na}$ ), and N-benzoyl-DL-arginine $p$-nitroanilide (BAPA) - were determined. Aliquots of $10 \mu \mathrm{L}$ of sample solution and $90 \mu \mathrm{L}$ of $50 \mathrm{mM}$ Tris- $\mathrm{HCl}$ buffer ( $\mathrm{pH} 9.0$ ) containing $1 \mathrm{mM}$ of each substrate were added to 96 -well plates and incubated at $37{ }^{\circ} \mathrm{C}$. The change in absorbance at $405 \mathrm{~nm}$ was measured. One unit of protease activity corresponded to the amount of enzyme that released $1 \mu \mathrm{mol} p$-nitroaniline per minute.

\subsubsection{Optimal $\mathrm{pH}$ and temperature}

The optimal $\mathrm{pH}$ for enzymatic activity was determined using $50 \mathrm{mM}$ citrate buffer at $\mathrm{pH} 4,5$, and 6 ; $50 \mathrm{mM}$ phosphate buffer at $\mathrm{pH} 6,7$, and $8 ; 50 \mathrm{mM}$ Tris$\mathrm{HCl}$ buffer at $\mathrm{pH} 8$ and 9 ; and $50 \mathrm{mM}$ glycine- $\mathrm{NaOH}$ buffer at $\mathrm{pH} 9$ and 10. Activity was determined using $\mathrm{SAAPF} p \mathrm{Na}$. The optimal temperature was determined using $50 \mathrm{mM}$ Tris-HCl buffer (pH 9.0) and SAAPF $p \mathrm{Na}$ at $20,30,37,40,45$, and $50^{\circ} \mathrm{C}$.

\subsubsection{Inhibition study}

The effects of different protease inhibitors on the activity of the recombinant protein were measured in $50 \mathrm{mM}$ Tris- $\mathrm{HCl}$ buffer ( $\mathrm{pH} 9.0$ ) containing $1 \mathrm{mM} \mathrm{SAAPF} p \mathrm{Na}$ at $37{ }^{\circ} \mathrm{C}$. For inhibition assay, phenylmethylsulfonyl fluoride (PMSF), $N$-tosylL-lysine chloromethyl ketone (TLCK), pepstatin A, ethylenediaminetetraacetic acid (EDTA) (Nacalai Tesque, Kyoto, Japan), 4-(2-aminoethyl) benzenesulfonyl fluoride (AEBSF), TPCK (Sigma Aldrich), antipain, leupeptin, and E-64 (Peptide institute Inc., Osaka, Japan) were used. 


\section{RESULTS}

\subsection{Separation and identification of proteases from honeybee queen larvae}

In the previous report, we found protease fractions including chymotryptic and carboxy peptidyl activities from honeybee queen larvae (Matsuoka et al. 2012). For the mass analysis of honeybee larval proteases, we separated honeybee queen larval proteins by cation exchange and gel filtration chromatography according to our previous report. Activities of fractions including carboxypeptidase activity (fraction I) or chymotryptic activity (fraction II) were detected with substrates, Z-Gly-Phe or SAAPF $p \mathrm{Na}$, respectively. The fractions were separated by SDSPAGE (Figure 1a, b).

Each protein that was obtained from SDSPAGE gel was analyzed by LC-MS/MS (Table I). The band of number 4 that was about $40 \mathrm{kDa}$ of fraction I (Figure 1a) was identified to a protein carboxypeptidase-B-like protease (XP_623727), and the band of number 1 that was about $25-28 \mathrm{kDa}$ protein of fraction II
(Figure 1b) was identified to a chymotrypsinlike protease (XP_394370) from the honeybee genome database. These results were compatible with the results of the enzyme assay for SAAPF $p \mathrm{Na}$ or Z-Gly-Phe.

\subsection{Expression and purification of recombinant chymotrypsin-like protease}

The identified chymotrypsin-like protease was expressed by $E$. coli expression system. Recombinant $E$. coli lysate was analyzed by SDS-PAGE (Figure 2a). IPTG induced an expression of a protein with a molecular weight of about $53 \mathrm{kDa}$. The molecular weight of the recombinant chymotrypsin-like protease was expected to be about $26 \mathrm{kDa}$ and conjugated with a GST-tag of $26 \mathrm{kDa}$. As recombinant GST-chymotrypsin was expressed as an insoluble protein, it was solubilized and refolded using a Rapid GST Inclusion Body Solubilization and Renaturation Kit. After refolding, the GSTtagged chymotrypsin was collected using glutathione sepharose 4B beads. The GST-tag was
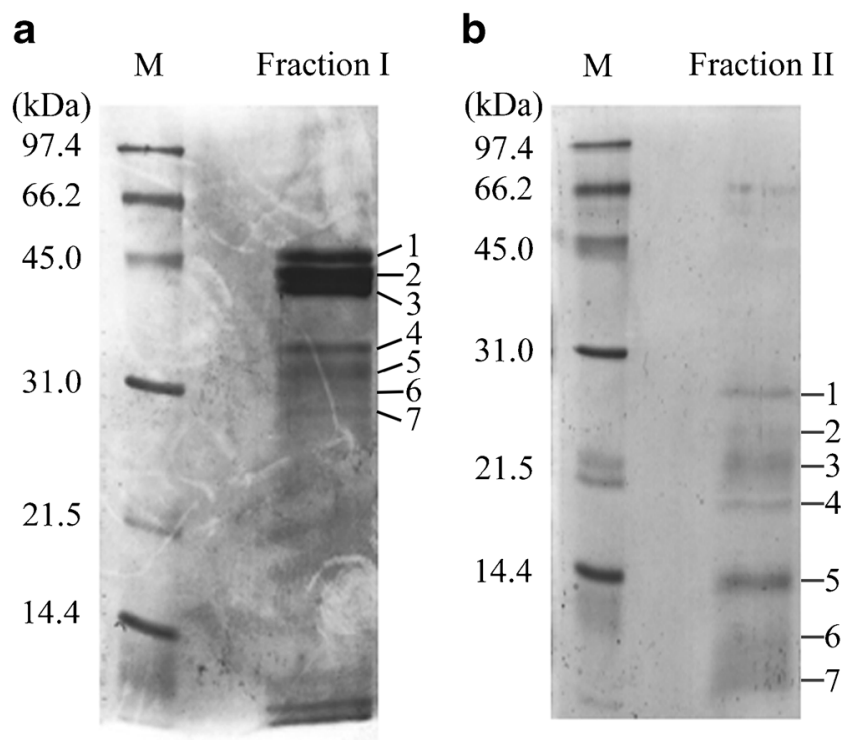

Figure 1. Separation of fractions containing carboxypeptidase-like (fraction I) and chymotrypsin-like (fraction II) activities from honeybee queen larvae. a The proteins contained in fraction I were separated by SDS-PAGE, and the numbers indicate the protein spots excised for ESI-ion trap MS. b The proteins contained in fraction II were separated by SDS-PAGE, and the numbers indicate the protein spots excised for ESI-ion trap MS. 
Table I. Identification of proteases in carboxypeptidase-like and chymotrypsin-like protease fractions.

\begin{tabular}{lclll}
\hline Sample & Accession number & \multicolumn{1}{c}{ Name } & Race & Mass \\
\hline Fraction I-4 & XP_623727 & Carboxypeptidase-B like & Apis mellifera & 47,969 \\
Fraction II-1 & XP_394370 & Chymotrypsin-1 & Apis mellifera & 28,079 \\
\hline
\end{tabular}

cleaved from solubilized chymotrypsin with thrombin (Figure 2b). The size of the obtained protein corresponded to the estimated size of about $26 \mathrm{kDa}$.

\subsection{Optimum pH and temperature for the hydrolysis of SAAPF $p$ Na}

The $\mathrm{pH}$ dependence of recombinant protease activity is shown in Figure 3a. Recombinant protease showed maximum activity for SAAPF $p \mathrm{Na}$ at $\mathrm{pH}$ 9.0. The activity at $\mathrm{pH} 7$ was about half that seen at $\mathrm{pH}$ 9. The effects of temperature on recombinant protease activity were shown in Figure $3 b$. Recombinant protease activity was highest at $40{ }^{\circ} \mathrm{C}$. This recombinant protease showed maximum activity at alkaline $\mathrm{pH}$, and the enzyme did not have cold adaptation or heat resistance.

\subsection{Activities of the recombinant protease with different substrates}

To investigate the specificity of recombinant protease, its activities against several substrates of serine proteases were investigated as shown in Figure 4. The activities toward elastase (SAAPL $p \mathrm{Na}$ and SAAA $p \mathrm{Na}$ ) and trypsin (BAPA) were lower than that for the chymotrypsin substrate, SAAPF $p$ Na. The relative activities against SAAPL $p$ Na, SAAA $p$ Na, and BAPA were $32.7,13.5$, and $8.16 \%$ of SAAPF $p \mathrm{Na}$, respectively. These results suggested that the recombinant enzyme was a chymotryptic protease.

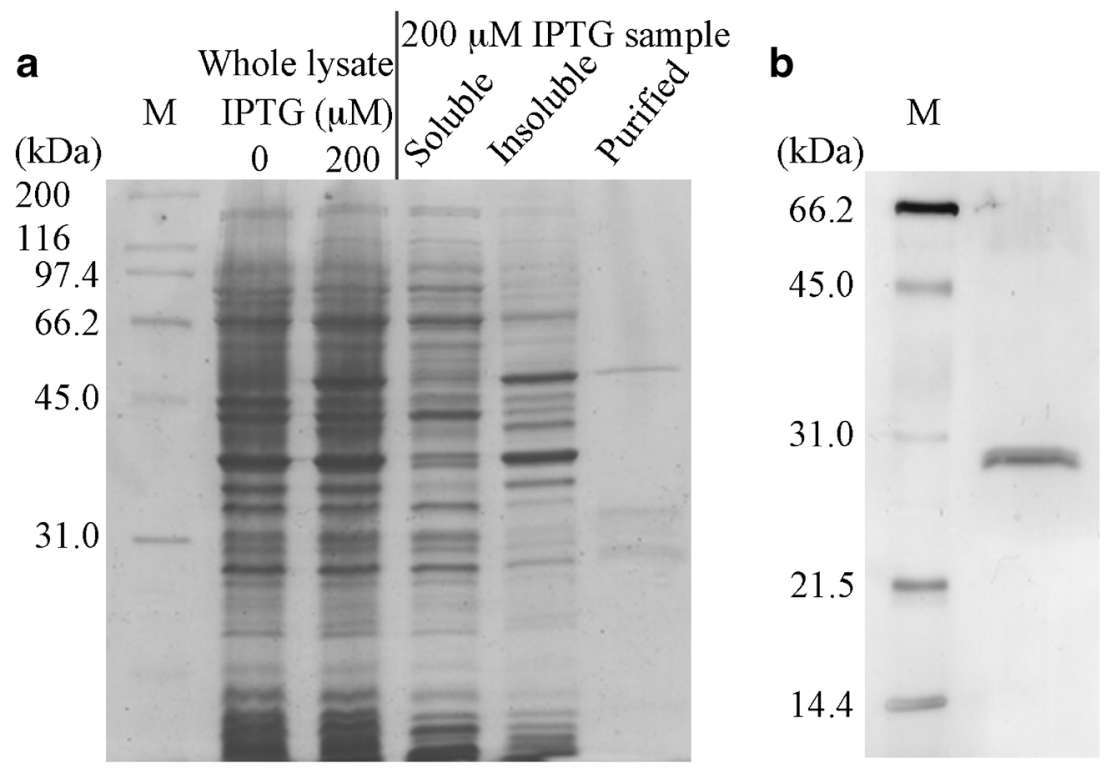

Figure 2. Expression and purification of recombinant chymotrypsin-like protease. a SDS-PAGE analysis with CBB staining of recombinant chymotrypsin-like protease extracted from $E$. coli lysate. In the left panel, each lane shows whole $E$. coli lysate without and with IPTG stimulation. In the right panel, each lane shows soluble and insoluble contents of $E$. coli lysate with IPTG stimulation and proteins purified by glutathione sepharose 4B beads. b SDSPAGE analysis with silver staining of recombinant protein after thrombin treatment. 
a

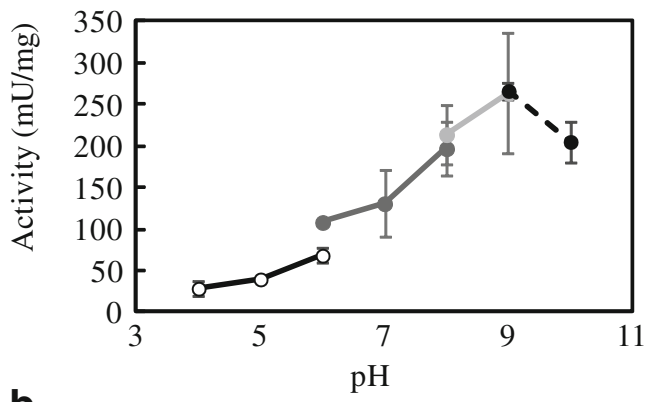

b

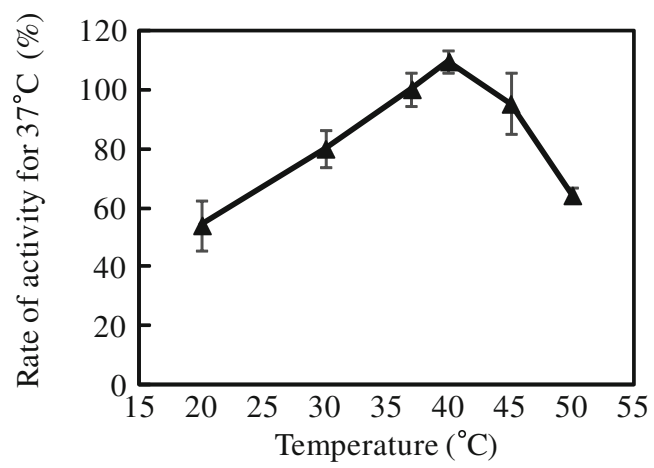

Figure 3. Optimum $\mathrm{pH}$ and temperature conditions for chymotryptic activity. a Effects of $\mathrm{pH}$ on chymotryptic activity. Enzyme activities were measured at various $\mathrm{pH}$ values using SAAPF $p \mathrm{Na}$ as a substrate at $37^{\circ} \mathrm{C}$. For reaction buffer, $50 \mathrm{mM}$ citrate buffer ( $\mathrm{pH} 4$ and 5 , white point and black line), $50 \mathrm{mM}$ phosphate buffer ( $\mathrm{pH} 6$, 7 , and 8 , thick gray point and line ), $50 \mathrm{mM}$ Tris- $\mathrm{HCl}$ buffer ( $\mathrm{pH} 8$ and 9, thin gray point and line), and $50 \mathrm{mM}$ glycine- $\mathrm{NaOH}$ buffer ( $\mathrm{pH} 9$ and 10, black point and broken line) were used. b Effects of temperature on chymotryptic activity. Enzyme activities were measured at various temperatures using SAAPF $p$ Na as a substrate at $\mathrm{pH}$ 9. Data are presented as mean $\pm \mathrm{SD}$.

\subsection{Effects of protease inhibitors on the hydrolysis of SAAPF $p$ Na}

The effects of protease inhibitors on the hydrolysis of SAAPF $p$ Na by the recombinant protease were shown relative to the activity of the sample without inhibitors in Table II. PMSF strongly inhibited the activity. In addition, antipain also showed an inhibitory effect. Both of these inhibitors can inhibit the activities of serine-type proteases. On the other hand, pepstatin A, an aspartic protease inhibitor, and E-64, a cysteine protease

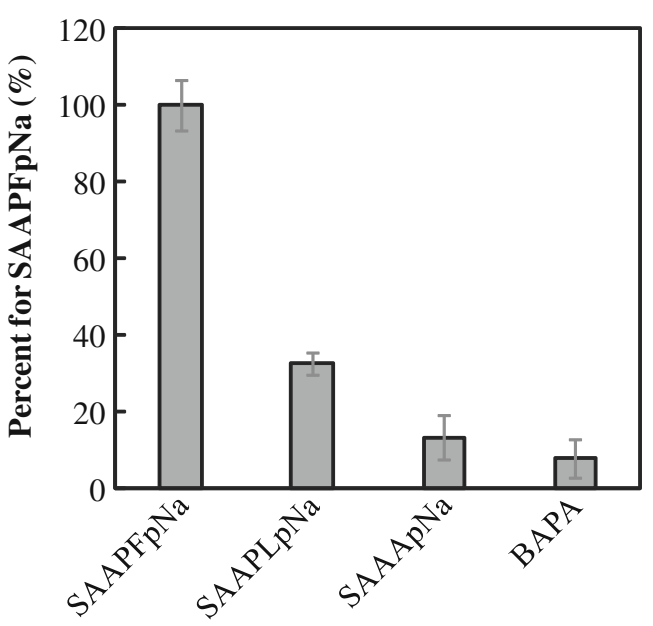

Substrate

Figure 4. Substrate specificities of the recombinant chymotrypsin-like protease. Enzyme activities were measured with each substrate at $\mathrm{pH} 9,37^{\circ} \mathrm{C}$. The data indicate activities relative to that against $\mathrm{SAAPF} p \mathrm{Na}$ $(100 \%)$. Data are presented as mean \pm SD.

inhibitor, did not inhibit the activity of the recombinant protease. Based on these results, the recombinant protease was regarded as a serine protease. EDTA, a metalloprotease inhibitor, showed a weak inhibitory activity, and AEBSF, generally used as a substitute for PMSF, and leupeptin, an inhibitor of several serine- or cysteine-type proteases, had weak inhibitory activities. In addition, neither TPCK nor TLCK inhibited the activity of the recombinant protease. These results suggested that the recombinant chymotrypsin-like protease had an active site that was different from mammalian chymotrypsin.

\section{DISCUSSION}

The compositions of digestive proteases of honeybee are different depending on the caste, stage (larva or adult), and age mainly because of differences in food. Previous reports regarding honeybee digestive proteases indicated that trypsin-like and chymotrypsin-like proteases are involved in the digestion of food in adult worker bees (Giebel et al. 1971; Dahlmann et al. 1978; Moritz and Crailsheim 1987). However, there 
Table II. Effects of protease inhibitors on recombinant chymotrypsin-like protease.

\begin{tabular}{lccc}
\hline Name & Concentration & Inhibition type & Inhibition (\%) \\
\hline PMSF & $1 \mathrm{mM}$ & Serine & $78.1 \pm 1.62$ \\
AEBSF & $1 \mathrm{mM}$ & Serine & $16.3 \pm 9.38$ \\
EDTA & $1 \mathrm{mM}$ & Metallo & $20.9 \pm 3.99$ \\
TLCK & $0.1 \mathrm{mM}$ & Trypsin & 0 \\
TPCK & $0.1 \mathrm{mM}$ & Chymotrypsin & 0 \\
Leupeptin & $10 \mu \mathrm{M}$ & Serine, cysteine & $24.7 \pm 6.98$ \\
Antipain & $10 \mu \mathrm{M}$ & Serine, cysteine & $37.6 \pm 1.27$ \\
Pepstatin A & $10 \mu \mathrm{M}$ & Aspartic & 0 \\
E-64 & $10 \mu \mathrm{M}$ & Cysteine & 0 \\
\hline
\end{tabular}

Data are presented as mean $\pm \mathrm{SD}$

have been few reports regarding the digestive proteases of the queen or larvae of the honeybee.

In this study, we identified two proteases from the fractions that were separated from the homogenate of 3-day-old honeybee queen larvae that could hydrolyze the substrate for carboxypeptidase, Z-Gly-Phe, or a substrate for chymotrypsin, SAAPF $p$ Na, respectively. Mass spectrometry and Mascot search suggested that these activities were derived from proteins similar to carboxypeptidaseB (XP_623727) or chymotrypsin (XP_394370) of A. mellifera (Figure 1, Table I). Therefore, we attempted to express the chymotrypsin-like protease in E. coli.

The $26-\mathrm{kDa}$ chymotrypsin-like protease produced in E. coli (Figure 2) showed chymotryptic activity. The activity was highest at $\mathrm{pH} 9$ and $40{ }^{\circ} \mathrm{C}$ (Figure 3 ). As the temperature of a honeybee colony is maintained at roughly $35{ }^{\circ} \mathrm{C}$ for normal brood development (Jones et al. 2004), the optimum temperature of the recombinant protease seemed to coincide with the living environment of honeybee larvae. Furthermore, the optimum $\mathrm{pH}$ of the enzyme was in the alkaline range. Most insect chymotrypsin-like enzymes separated from the midgut of adults and larvae have $\mathrm{pH}$ optima in the range of $\mathrm{pH} \mathrm{8-9} \mathrm{(Terra} \mathrm{and}$ Ferreira 1994). Although the intestinal $\mathrm{pH}$ of the adult honeybee is weakly acidic and that of larvae is approximately neutral (Herbert and Shimanuki 1983), chymotrypsin-like and trypsin-like enzymes of adult honeybees also showed high levels of activity in the range of $\mathrm{pH} 7-9$ (Moritz and
Crailsheim 1987; Jimenez and Gilliam 1989). These reports suggest optimum $\mathrm{pH}$ of larval digestive enzymes is in the alkaline range. The result of $\mathrm{pH}$ dependence of the recombinant chymotrypsin-like protease from honeybee larvae was consistent with these previous reports.

The recombinant chymotrypsin-like protease hydrolyzed a chymotrypsin substrate, SAAPF $p \mathrm{Na}$, more strongly than trypsin and elastase substrates (Figure 4). PMSF and antipain inhibited the activity, but pepstatin A and E-64 did not (Table II). These results suggested that this enzyme was a serinetype protease. Moreover, EDTA showed a weak inhibitory activity. Although EDTA is typically a metalloprotease inhibitor, it has been reported that some chymotrypsin- or trypsin-like digestive enzymes, such as that those of mealworm (Vinokurov et al. 2006; Elpidina et al. 2005; Tsybina et al. 2005), cockchafer (Wagner et al. 2002), beet armyworm (Herrero et al. 2005), and scorpion (Louati et al. 2011), were weakly inhibited by EDTA. On the other hand, TLCK and TPCK did not show inhibitory activity against the recombinant protease. The chymotrypsin-like enzymes of larval mealworms (Elpidina et al. 2005) and fire ants (Whitworth et al. 1998) were unaffected by both TPCK and TLCK. In addition, Botos et al. (2000) reported that the chymotrypsin of the fire ant is markedly similar but showed differences beyond those found among homologs from different mammalian systems. Thus, our protease was considered to have a different reaction mechanism from mammalian chymotrypsin. 
Further structural analyses of the protease, such as crystallography, are required to clarify the reaction mechanism.

Giebel et al. (1971) found four endopeptidase fractions from adult honeybee and reported that the adult queen bee and worker larvae lacked three of these proteases. The queen bee and worker larvae only had a protease with a molecular weight of about $30 \mathrm{kDa}$ that did not cleave trypsin substrates (BAEE and BANA) and chymotrypsin substrates (ATEE, APNE, and GlupNa), and its activity was inhibited by PMSF and TPCK. Thus, the protease that they found from the queen bee was different from our chymotrypsin-like protease. In this study, we expressed the chymotrypsinlike protease found in the whole lysate of honeybee queen larvae in E. coli, and therefore, we did not confirm whether it was localized in the midgut. Further studies are required to determine the localization of the protein.

From the above results, we designate the recombinant protease as a honeybee chymotrypsinlike protease (HCLPase). This is the first report of the identification of a protease in honeybee larvae. Recently, Kamakura (2011) demonstrated that the $\mathrm{RJ}$ protein royalactin played a critical role in honeybee differentiation. However, it is not clear how the honeybee queen and larvae digest RJ and utilize it for their development and physiology. The study of proteases of honeybee larvae may clarify not only the development and differentiation of the honeybee but also the mechanism of action of RJ as health food and allow the development of further functional value.

\section{ACKNOWLEDGMENTS}

We wish to thank Dr. Yokichi Hayashi of the Department of Life Science, Asahikawa Medical Collage, for helpful suggestions. We also thank Kenji Ota, Suzuyo Watanabe, Yuri Kashima, and Satoshi Kanematsu of Akitaya Honten Co., Ltd. for their help in the procurement and preparation of larval samples.

Expression et caractérisation d'une protéase analogue à la chymotrypsine chez les larves de l'abeille, Apis mellifera

Larve / reine / protéase analogue à la chymotrypsine
Expression und Charakterisierung einer Chymotrypsinähnlichen Protease in Larven der Honigbiene, Apis mellifera

Apis mellifera / Königinnenlarven / Chymotrypsinähnliche Protease

\section{REFERENCES}

Botos, I., Meyer, E., Nguyen, M., Swanson, S.M., Koomen, J.M., Russell, D.H., Meyer, E.F. (2000) The structure of an insect chymotrypsin. J. Mol. Biol. 298, 895-901

Brødsgaard, H.F., Brødsgaard, C.J., Hansen, H., Lövei, G.L. (2003) Environmental risk assessment of transgene products using honey bee (Apis mellifera) larvae. Apidologie 34, 139-145

Burgess, E.P.J., Malone, L.A., Christeller, J.T. (1996) Effect of two proteinase inhibitors on the digestive enzymes and survival of honey bees (Apis mellifera). J. Insect Physiol. 42, 823-828

Dahlmann, B., Jany, K.D., Pfleiderer, G. (1978) The midgut endopeptidase of the honey bee (Apis mellifica): comparison of the enzymes in different ontogenetic stages. Insect Biochem. 8, 203-211

Elpidina, E.N., Tsybina, T.A., Dunaevsky, Y.E., Belozersky, M.A., Zhuzhikov, D.P., Oppert, B. (2005) A chymotrypsin-like proteinase from the midgut of Tenebrio molitor larvae. Biochimie 87, 771-779

Giebel, W., Zwilling, R., Pfleiderer, G. (1971) The evolution of endopeptidases-XII. The proteolytic enzymes of the honeybee (Apis mellifica L.). Comp. Biochem. Physiol. 38B , 197-210

Guo, H., Ekusa, A., Iwai, K., Yonekura, M., Takahata, Y., Morimatsu, F. (2008) Royal jelly peptides inhibit lipid peroxidation in vitro and in vivo. J. Nutr. Sci. Vitaminol. 54, 191-195

Guo, H., Kouzuma, Y., Yonekura, M. (2009) Structures and properties of antioxidative peptides derived from royal jelly protein. Food Chem. 113, 238-245

Herbert Jr., E.W., Shimanuki, H. (1983) Effect of diet pH on the consumption, brood rearing, and $\mathrm{pH}$ of worker jelly produced by caged honey bees. Apidologie 14, 191-196

Herrero, S., Combes, E., Van Oers, M.M., Vlak, J.M., de Maagd, R.A., Beekwilder, J. (2005) Identification and recombinant expression of a novel chymotrypsin from Spodoptera exigua. Insect Biochem. Mol. Biol. 35, 1073-1082

Hidaka, S., Okamoto, Y., Uchiyama, S., Nakatsuoma, A., Hashimoto, K., Ohnishi, S.T., Yamaguchi, M. (2006) Royal jelly prevents osteoporosis in rats: beneficial effects in ovariectomy model and in bone tissue culture model. eCAM 3, 339-348

Honeybee Genome Sequencing Consortium (2006) Insights into social insects from the genome of the honeybee Apis mellifera. Nature 443, 931-949 
Jimenez, D.R., Gilliam, M. (1989) Age-related changes in midgut ultrastructure and trypsin activity in the honey bee, Apis mellifera. Apidologie 20, 287-303

Jones, J.C., Myerscough, M.R., Graham, S., Oldroyd, B.P. (2004) Honey bee nest thermoregulation: diversity promotes stability. Science 305, 402-404

Kamakura, M. (2011) Royalactin induces queen differentiation in honeybees. Nature 473, 478-483

Louati, H., Zouari, N., Miled, N., Gargouri, Y. (2011) A new chymotrypsin-like serine protease involved in dietary protein digestion in a primitive animal, Scorpio maurus: purification and biochemical characterization. Lipids Health Dis. 10, 121

Matsui, T., Yukiyoshi, A., Doi, S., Sugimoto, H., Yamada, H., Matsumoto, K. (2002) Gastrointestinal enzyme production of bioactive peptides from royal jelly protein and their antihypertensive ability in SHR. J. Nutr. Biochem. 13, 80-86

Matsuoka, T., Kawashima, T., Nakamura, T., Kanamaru, Y., Yabe, T. (2012) Isolation and characterization of proteases that hydrolyze royal jelly proteins from queen bee larvae of the honeybee, Apis mellifera. Apidologie 43, 685-697

Moore, S. (1968) Amino acid analysis: aqueous dimethyl sulfoxide as solvent for the ninhydrin reaction. J. Biol. Chem. 243, 6281-6283

Moritz, B., Crailsheim, K. (1987) Physiology of protein digestion in the midgut of honeybee (Apis mellifera L.). J. Insect Physiol. 12, 923-931

Nagai, T., Inoue, R., Suzuki, N., Nagashima, T. (2006) Antioxidant properties of enzymatic hydrolysates from royal jelly. J. Med. Food 9, 363-367

Nakasa, T., Ueda, S., Nakatsuka, M., Okinaka, O. (2003) Effect of protease-treated royal jelly on plasma and liver lipids in rats fed on a high fat plus high cholesterol diet. Nippon Shokuhin Kagaku Kogaku Kaishi 10, 463-467

Niu, K., Guo, H., Guo, Y., Ebihara, S., Asada, M., Ohrui, T., Furukawa, K., Ichinose, M., Yanai, K., Kubo, Y.,
Arai, H., Okazaki, T., Nagatomi, R. (2013) Royal jelly prevents the progression of sarcopenia in aged mice in vivo and in vitro. J. Gerontol. A Biol. Sci. Med. Sci. 68, 1482-1492

Shevchenko, A., Wilm, M., Vorm, O., Mann, M. (1996) Mass spectrometric sequencing of proteins silverstained polyacrylamide gels. Anal. Chem. 68, 850-858

Terra, W.R., Ferreira, C. (1994) Insect digestive enzymes: properties, compartmentalization and function. Comp. Biochem. Physiol. 109B, 1-62

Tokunaga, K., Yoshida, C., Suzuki, K., Maruyama, H., Futamura, Y., Araki, Y., Mishima, S. (2004) Antihypertensive effect of peptides from royal jelly in spontaneously hypertensive rats. Biol. Pharm. Bull. 27, 189-192

Tsybina, T.A., Dunaevsky, Y.E., Belozersky, M.A., Zhuzhikov, D.P., Oppert, B., Elpidina, E.N. (2005) Digestive proteinases of yellow mealworm (Tenebrio molitor) larvae: purification and characterization of a trypsin-like proteinase. Biochemistry (Moscow) 70, 370-377

Vinokurov, K.D., Elpidina, E.N., Oppert, B., Prabhakar, S., Zhuzhikov, D.P., Dunaevsky, Y.E., Belozersky, M.A. (2006) Diversity of digestive proteinases in Tenebrio molitor (Coleoptera: Tenebrionidae) larvae. Comp. Biochem. Physiol. B 145, 126-137

Wagner, W., Möhrlen, F., Schnetter, W. (2002) Characterization of the proteolytic enzymes in the midgut of the European cockchafer, Melolontha melolontha (Coleoptera: Scarabaeidae). Insect Biochem. Mol. Biol. 32 , 803-814

Whitworth, S.T., Blum, M.S., Travis, J. (1998) Proteolytic enzymes from larvae of the fire ant, Solenopsis invicta : isolation and characterization of four serine endopeptidases. J. Biol. Chem. 273, 14430-14434

Zou, Z., Lopez, D.L., Kanost, M.R., Evans, J.D., Jiang, H. (2006) Comparative analysis of serine protease-related genes in the honey bee genome: possible involvement in embryotic development and innate immunity. Insect Biochem. Mol. Biol. 15, 603-614 